\title{
Design and Application of a High-performance True Triaxial Stress Cell
}

\author{
A Rezagholilou* and M Sarmadivaleh \\ Department of Petroleum Geomechanics, Curtin university, Australia
}

Submission: November 22, 2019; Published: December 16, 2019

*Corresponding author: A Rezagholilou, Department of Petroleum Geomechanics, Curtin university, Australia

Abstract

Conventional triaxial tests are for axisymmetric stress condition, which is not necessarily correct for deep rock layers. Thus, orthotropic stress conditions and pore pressure are better simulated by new generation of high-performance True Triaxial Stress Cell (TTSC). New TTSC in Curtin university allows stresses up to $70 \mathrm{MPa}$ on a $50 \times 50 \times 50 \mathrm{~mm}$ cube of the rock sample. Additionally, pore pressure can be up to $20 \mathrm{MPa}$ and temperature up to 70oC. Six sets of LVDT strain gauges and 24 acoustic transducers can monitor all deformations and crack events during fracturing of a sample. Through a hole in the center of the rock, a fluid can be injected to simulate hydraulic fracturing, or investigate fault reactivation during fluid injection. All of events are monitored in real-time manner using ultrasonic seismic transducers around the sample. Further details of this equipment are explained in this paper.

Keywords: True Triaxial Stress Cells; Triaxial tests; Geomechanics

\section{Introduction}

In rock mechanics, estimation of the strength and deformations under various stress states are essential. Conventional triaxial tests are for cylindrical samples whereas a rock sample is subjected to circumferential confining pressure $\left(\sigma_{2}=\sigma_{3}\right)$ under an axial stress $\left(\sigma_{1}\right)$. This case is only valid for seismically normal stress condition [1]. However, there is often orthogonal stress condition $\left(\sigma_{1} \neq \sigma_{2} \neq \sigma_{3}\right)$ in deep rock layers, which affects the drilling stability, seal integrity in petroleum engineering [2]. This condition can be due to anisotropy of rock properties, faulting systems and various tectonic conditions. Accordingly, cubic rock samples are tested in True Tri-axial Stress Cells (TTSC). These facilities replicate the real stress environment in ground to develop the knowledge of rock mechanics effectively [3-5].

\section{Background}

Researchers at Curtin University developed the first cell of this kind in Australia in 2010 to investigate various geomechanical models including hydraulic fracturing, sand production etc. [6]. It was to accommodate the samples up to $300 \mathrm{~mm}$ dimensions like the one developed by Haimson et al. [7]. It could provide lateral and vertical stresses without surrounding pore pressures. Accommodation of small samples requires spacers to transfer the loads over samples in various sizes. Deformations in each direction can be recorded by Linear variable differential transducers (LVDT) attached to each loading ram. Syringe or Hydraulic pumps with pressure capacity up to $103.5 \mathrm{MPa}$ can be used to exert stresses over surfaces. For hydraulic fracturing, fluid injection can be either in constant flow rate with a maximum capacity of $650 \mathrm{cc} / \mathrm{hr}$ or constant pressures or any other loading patterns introduced to syringe pumps. Deflections of rams also can be up to $20 \mathrm{~mm}$, which is quite enough for most cases. The main capability of this facility is acoustic emission and acquisition system. This feature enables users to monitor acoustic events due to any fracture move. Sixteen sensors in real time are responsible to capture the signals from all directions to map crack propagation due to stress anisotropy.

\section{New TTSC Facility}

With support of National Geosequestration Laboratory (NGL), new equipment was developed by Curtin University in 2016. It was to deliver innovative solutions into carbon storages projects in Australia. This cell is for $50 \mathrm{~mm}$ cube samples with capacity of providing pore pressure around or into samples via hot fluid or gas as shown in Figure 1. The design and fabrication of $50 \mathrm{~mm}$ cell has been inspired basically by $30 \mathrm{~cm}$ standard TTSC built in 2010 and the one developed in Petrobras Research and Development Center [8]. The main difference of this new cell with the previous ones in its internal design and functionality mainly about sealing systems that are closely based on similar small cell in Brazil. This new cell of $50 \mathrm{~mm}$ cell has injection or pore pressure systems adjustable according to high temperature, corrosion resistance requirements 
as well as delicate acoustic system. This cell is easier to assemble with reduced number of components specifically for load system. This in turn clearly lowers the associated maintenances, which are a challenge in its maintenance. The seals are mostly compressional with broad area for crushing of Viton or Polyurethane sleeve plus 0-rings as double barrier any likely leakage. Steel grade was 4140 because of its higher strength and availably of $70 \mathrm{~cm}$ steel blocks in Perth for machining purposes.

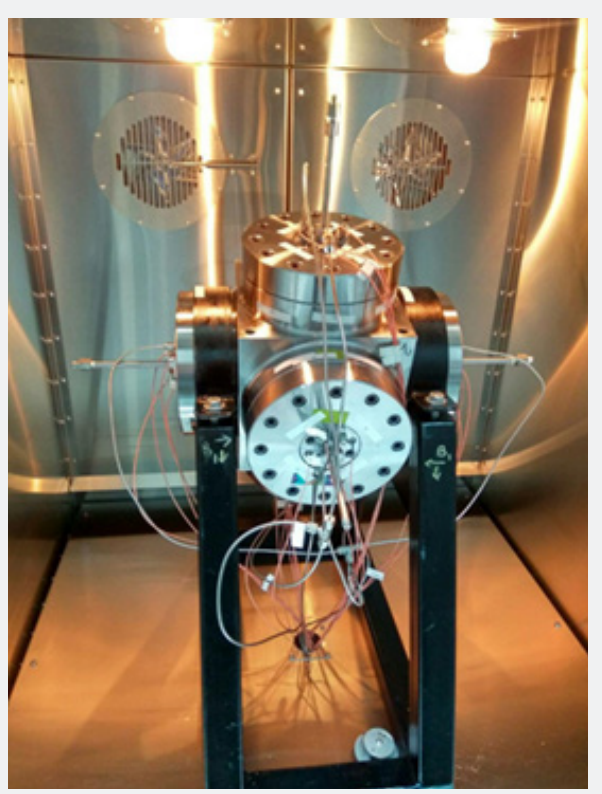

Figure 1: General configuration of new 50mm TTSC.

\section{Ultrasonic System}

This TTSC primarily is built for laboratory-based $\mathrm{CO}_{2}$ injection studies. Previous cell in 2010 included ultrasonic transducers on all six sides of rock specimen, whereas transducers being pressed by springs within recessed indentations anticipated on loading faces [9]. New 50mm TTSC have 4 transducers per face, amounting to a total of 24 transducers each being sampled at every $0.1 \mu \mathrm{sec}$ $[10,11]$. All transducers will have the ability to record data in listen mode continuously recorded into a standard memory using software based on Labview. Once an event is observed (a peak in amplitude), the signal timing is adjustable to $200 \mu \mathrm{sec}$ before the event and $300 \mu \mathrm{sec}$ after the event. A knowledge of the velocity field of the block is obtained by pulsing all transducers once with all other transducers recording, to provide a calibration database of the velocity field of the block. Using this database, a 3D location and display of each event's origin is computed as conventionally processed in acoustic emission processing $[12,13]$.

\section{Conclusion}

The new $50 \mathrm{~mm}$ TTSC system provides unique opportunities to expand the knowledge of advanced tests in Geomechanics by allowing real time monitoring of cracks in rock specimens.

\section{Acknowledgement}

This research was supported by National Geosequestration Laboratory (NGL). We thank our colleagues from Petroleum
Geomechanics Group (PPG) in Curtin University who provided insight and expertise that greatly assisted the research

\section{Conflict of Interest}

The authors certify that they have NO affiliations with or involvement in any organization or entity with any financial interest, or non-financial interest in the subject matter or materials discussed in this manuscript.

\section{References}

1. Fjar E, Holt RM, Raaen A, Risnes R, Horsrud P (2008) Petroleum related rock mechanics 53: Elsevier.

2. Adnoy B, Looyeh R (2019) Petroleum rock mechanics: drilling operations and well design: Gulf Professional Publishing.

3. Behnoudfar P, Asadi MB, Gholilou A, Zendehboudi S (2019) A new model to conduct hydraulic fracture design in coalbed methane reservoirs by incorporating stress variations. Journal of Petroleum Science and Engineering 174: 1208-1222.

4. Kwasniewski M, Li X, Takahashi M (2012) True triaxial testing of rocks 4: CRC Press.

5. Skea C, Rezagholilou A, Far PB, Gholami R, Sarmadivleh M (2018) An approach for wellbore failure analysis using rock cavings and image processing 10(5): 865-878.

6. Rasouli V, Evans B (2010) A true triaxial stress cell to simulate deep downhole drilling conditions 50(1): 61-70.

7. Haimson B, Chang C (2000) A new true triaxial cell for testing mechanical properties of rock, and its use to determine rock strength 
and deformability of Westerly granite. International Journal of Rock Mechanics and Mining Sciences 37(1-2): 285-296.

8. Villarroel FM, Júnior EV, De Azevedo VA, Missagia RM, Bloch M (2009) Breakouts: physical and numerical modeling. Paper presented at the $11^{\text {th }}$ International Congress of the Brazilian Geophysical Society \& EXPOGEF, Salvador, Bahia, Brazil, pp. 24-28.

9. Nabipour A, Evans B, Sarmadivaleh M (2011) Active monitoring of hydraulic fracture propagation: an experimental and numerical study 51(1): 479-486.

10. Feng R, Zhang Y, Rezagholilou A, Roshan H, Sarmadivaleh M (2019) Brittleness Index: From Conventional to Hydraulic Fracturing Energy Model, pp. 1-15.
11. Reza Gholilou A, Salemi H, Tarom N, Behnoudfar P, Sarmadivaleh M (2019) Experimental investigation of fluid thermal effects on fracture brittleness. J The APPEA Journal 59(1): 457-463.

12. Rezagholilou A, Vialle S, Madadi M (2017) Determination of safe mud window considering time-dependent variations of temperature and pore pressure: Analytical and numerical approaches 2:1-12.

13. Salemi H, Rezagholilou A, Asadi S, Iglauer S, Sarmadivaleh M (2017) Poroelastic effects of pore pressure-stress coupling on fault reactivation risks during gas injection. Paper presented at the $51^{\text {st }}$ US Rock Mechanics/Geomechanics Symposium.

\section{Your next submission with Juniper Publishers} will reach you the below assets

- Quality Editorial service

- Swift Peer Review

- Reprints availability

- E-prints Service

- Manuscript Podcast for convenient understanding

- Global attainment for your research

- Manuscript accessibility in different formats

( Pdf, E-pub, Full Text, Audio)

- Unceasing customer service

Track the below URL for one-step submission https://juniperpublishers.com/online-submission.php 